\title{
Blyden's Philosophy and Its Impact on West African Intellectuals: Case of J.E. Casely Hayford of the Gold Coast (Ghana)
}

\author{
Ahmed Bouchemal \\ Department of English \\ Faculty of Letters and Foreign Languages \\ Dialogue of Religions and Civilizations in the Mediterranean Basin Laboratory \\ Abou Bekr Belkaid University, Tlemcen, Algeria \\ Faiza Meberbeche Senouci \\ Department of English \\ Faculty of Letters and Foreign Languages \\ Abou Bekr Belkaid University, Tlemcen, Algeria
}

\begin{abstract}
This study examines the impact of Blyden's philosophy on J.E. Casely Hayford of the Gold Coast (Ghana). It exposes Blyden's ideas, a philosophy on Africans physical and intellectual emancipation, and points out the similarities in the thought of both men. Blyden toured different parts of West Africa and spoke with great intensity about the African problem and ways of its remedy. His ideas had a lot of influence at the time and precipitated the emergence of nationalist messiah who undertook a mission to redefine the African universe. This study examines the ideas and intellect of J.E.Casely Hayford and revealed that his thoughts were a potency of Edward Wilmot Blyden's philosophy. An examination of his ideas reveals how Joseph Ephraim Casely Hayford took an uncompromising stand against the derogatory and the glaring abuses of European colonialism. He shaped cultural nationalism that disdained the apparent repulsive and despotic colonial hegemony and fashioned a new outlook for fellow Africans to stand up as humans. This article concludes that Hayford, drawing on Blyden's philosophy, succeeded in fashioning a culture of protest against all forms of black degradation and thus presented a continuity in black political thought that remained up to present.
\end{abstract}

Keywords African problem, Casely Hayford,cultural nationalism Edward Wilmot Blyden, European Colonialism

Cite as: Bouchemal, A.,\& Senouci,F. M. (2020). Blyden's Philosophy and Its Impact on West African Intellectuals: Case of J.E. Casely Hayford of the Gold Coast (Ghana). Arab World English Journal for Translation \& Literary Studies 4 (2) 143 -156.

DOI: http://dx.doi.org/10.24093/awejtls/vol4no2.11 
AWEJ for Translation \& Literary Studies Volume, 4 Number 2 May 2020

Blyden's Philosophy and Its Impact on West African Intellectuals

Bouchemal \& Senouci

\section{Introduction}

The origins of Black Nationalism promulgated during the late eighteenth and the early nineteenth centuries. During this period, Africans grappled with questions of identity crisis. With the demoralizing effects of black enslavement and trafficking to the American continent, the Africans sensitized the plight of slaves and their campaign for their freedom. Their protests delineated slavery's detrimental effects and showed how blacks were disgusted and despoiled with the obtrusive and retarding force of Western civilization. Africans realized the fact that they had their peculiarities that set their social and economic systems different from that of the Westerners. A blind fusion of these systems into the western models would only result in the disruption and destruction of these systems.

As such, Africans sought white oppression as detrimental to their growth and was only a means to make Africans show shame in their blackness.

Within this time of great upheaval for Africa, Edward Wilmot Blyden came on top of the personalities who attempted to lift the veil of ignorance and stir the imagination of the public of the horrors of European colonialism. He placed complete responsibility of the black situation on Europeans, and questioned European appeals of "civilization" and "modernity" that drove them to fail and debase the African. In all, Blyden's ultimate goal was to provide an Afro-centric interpretation of Africans socio-cultural estate and mould new images for the Africans that recognized their history, culture, and well-being.

Yet many scholars have not acknowledged Blyden's impact on West African intellectuals. Blyden's philosophy has been credited with giving a totally theorization of Africans psyche, but the impact of his philosophy on West African intellectuals is scarcely recognized. The article contributes to the existing literature through a contextualization of Blyden's broader ideas and intellect within the racial, theological, and ideological thoughts of a Ghanaian Nationalist messiah: J.E. Casely Hayford. As such, the article consists of four sections. The first gives briefs on Blyden's early life and career. The second reviews his philosophy while the third traces Blyden's ideas and the emergence of West African nationalism. The last section reviews the impact of Blyden's philosophy on J.E. Casely Hayford. The article concludes with some findings and recommendations.

\section{Edward Wilmot Blyden: Early Life and Career}

Edward Wilmot Blyden was born on 3 August 1832 in Charlotte Amalie on the island of St. Thomas, the West Indies. His parents Romeo and Judith Blyden were ex-slaves brought to the island of St. Eustatius in 1794 (Lynch, 1967). His childhood was characterized by great socialization with the Jewish community at Charlotte Amalie, where he interacted with Jewish families and was amazed by their culture and religious practices. His intellectual advancement seemed to grow out of his contact with David Cardozo, a very influential Jewish intellectual. Cardozo helped Blyden study Hebrew and was very instrumental in shaping his philosophical and intellectual reflections on race, education, and religion. At the age of twelve, Blyden (as cited in

Arab World English Journal for Translation \& Literary Studies 
AWEJ for Translation \& Literary Studies Volume, 4 Number 2 May 2020

Blyden's Philosophy and Its Impact on West African Intellectuals

Bouchemal \& Senouci

Conyers, 1998, p.35) was a regular attender of a tailoring shop where he was allowed "a provision ...to attend school in the morning".

An outstanding achievement of his whole life came with his contact with the Rev. John Knox, a white priest at the Dutch Reformed Church at St. Thomas. Blyden (as cited in Conyers, 1998: p.37) described his friendship with Knox as one "which was of great benefit to me and gave a turn to all my life". By 1850, Blyden, with the help of Knox and the support of his parents, went to the Unites States. Knox had the plan of enrolling Blyden in the Rutgers Theological College in the United States. Unfortunately, Blyden's first visit to the United States was disappointing. The Theological College refused Blyden's admission because of his race. An action that disheartened Blyden and placed him in front of a "deep-seated prejudice" and detention to the right of education against people of the African race. Things worsened for Blyden with the issuance of the Fugitive Slave Law of 1850. The Law made it plain that "slavery for the free and the slave alike (and) a declaration of an open season for the slave kidnappers" (Gloria, 2014:p.253). After about several months in New York City, Blyden met Walter Lowrie, secretary of the Presbyterian Board of Foreign Missions, and John B. Pinny of the New York Colonization Society. The two men proposed for Blyden to repatriate to Liberia, where he could attain higher education at Alexander High School. Once Blyden decided to go to Liberia by 1851, he moved with a renewed vigor. Blyden seemed to embrace the appeals of many prominent Afro-Americans for a return to the African continent. According to Blyden, there was a "need to collect the scattered forces of the race, and there is no rallying-ground more favorable than Africa" (Spreading Pan-African Ideas, n.d 02).

Blyden's first stay in Liberia was of great importance to his intellectual and political career. At Alexander High school, Blyden proved his talent as an accomplished classicist (Conyers, 1998). He received courses in Latin, Greek, Geography, and Mathematics. He also had courses in Theology where he studied the Bible. The latter had revealed to him many aspects of Hebrew History that resembled African's experience with enslavement, persecution, and dislocation. Because of his great talent and mastery of many languages, Blyden quickly immersed himself in the political and intellectual life of the country. During these years, Blyden occupied many positions that helped disperse his ideas among West Africans. He served three terms as Secretary of State of Liberia (1864-1871), Ambassador of the Court of St. James (1877, 1879 and 18921894), and agent to the Sierra Leonean interior (1872-1895). As a journalist, Blyden edited the Liberia Herald (1855-1856) and the Negro, a Sierra Leonean newspaper, (1872-1873).

During his long journey as a scholar, theologian, and anthropologist and extended stays at Liberia, Sierra Leone, Lagos, and Nigeria, Blyden produced works of highly intellectual appeals. A Voice From Bleeding Africa (1856), The Negro in Ancient History (1869), and Christianity, Islam and the Negro Race (1887), to mention just a few, were instrumental in shaping his cultural, intellectual and spiritual philosophy. Through his philosophy, Blyden worked to oppose current racist theories that contemplated Africans and made them believe in their inferiority. He urged the Africans to fight European representations that strove to show Africans' mental retardation and indolence.

Arab World English Journal for Translation \& Literary Studies 
AWEJ for Translation \& Literary Studies Volume, 4 Number 2 May 2020

Blyden's Philosophy and Its Impact on West African Intellectuals

Bouchemal \& Senouci

\section{Blyden's Philosophy}

No doubt that the African personality presented the core of Blyden's philosophy. He sought to oppose European anthropological race theories that denigrated the African race and made it parasite upon the European. Blyden's African personality propounded the fact that the African had its peculiarities that made him unique, and any attempt at fusion with other systems would only result in the possible disruption of his own identity (Conyers, 1998). According to Blyden (as cited in Zack, 2017),

Let us do away with the sentiment of Race. Let us do away with out African personality and be lost, if possible, in another Race.' This is as wise or as philosophical as to say; let us do away with gravitation, with heat and cold and sunshine and rain. Of course, the Race in which these persons would be absorbed is the dominant race, before which, in cringing self-surrender and ignoble self-suppression they lie in prostrate admiration. (p.87)

Blyden had been at pains to show how European influences distorted the African personality. For Blyden, continuous European obliteration of Africans intellectual and cultural institutions was a "terrible homicide". By this, Blyden (1908) condemned western theories of human unity and alluded to the fact that each race "has developed for itself such a system or code of life as its environment has suggested" (p.10). Moreover, he affirmed that Europeans intentional erosion of these institutions precipitated the gradual erosion of the African personality. A process that stirred up the need to recognize the Negro problem and to show fellow Africans how to develop a race pride and an awareness of a distinctive cultural identity.

The African personality was utterly antithetical to the European personality. For Blyden, the African personality exhibited qualities of communalism, sympathy, spirituality, and cooperation (Lynch, 1967). He conveyed that these qualities made the Africans spiritually superior to the Europeans. Blyden (as cited in Conyers, 1998) made this clear in a letter to Booker T. Washington:

It is a small matter that the white man has not yet advanced to the point where he will invite a Negro to the prayer meeting. Perhaps he will never advance to that point. The Negro is on a different plane, religiously, from the white man. He has a more spiritual nature... (p.83)

Moreover, he advanced that African cooperative socialism was innate to the African personality. For Blyden (1908), the African society taught the individual "all work for each and each works for all" (p.12). Because of these qualities, the African personality heralded a close connection to nature. On the other hand, the European personality was "harsh, individualistic, competitive and combative" (Lynch, 1967). It had the tendency to subdue other races and place science over spirituality. In doing away with spirituality, Blyden (1888) claimed that the European personality sought "to divorce God from his works" and praise individualistic human achievements. A man became "an end" not "a means". An individual's intellectual and "pecuniary" might dictated that less powerful people should abstract their presence and be controlled by "the more favored race". In this respect, Blyden affirmed that the European personality became merely materialistic which

Arab World English Journal for Translation \& Literary Studies 
AWEJ for Translation \& Literary Studies Volume, 4 Number 2 May 2020

Blyden's Philosophy and Its Impact on West African Intellectuals

Bouchemal \& Senouci

led European mission in Africa to become a force preoccupied by materialistic needs of "intolerance and impracticable narrowness" (p280).

Blyden"s African personality was much more than a culturally-based philosophy (Conyers, 1998). It represented a holistic philosophy that entails political and educational ends. According to Blyden (as cited in Conyers, 1998),

The great point at which you should aim is not simply the information, but the formation of the mind. The formation of the mind being secured the information will take care of itself. Mere knowledge of itself is not power- but the ability to know how to use that knowledge - and this ability belongs only to the mind that is disciplined, trained, formed. (p.194)

Blyden made the point that mere knowledge of the African of his innate abilities was not enough. The African to survive, he should metamorphose understanding about the African personality into a dynamic for his social, political, and educational progress. As a dynamic political and educational creed, Blyden sought the African personality philosophy as a positive new start. Now, the African bestowed with the blessings of this philosophy should carve his path of progress. For Blyden, this progress demanded a whole re-conceptualization of the aims of education for Africans.

Education represented another dimension by which Blyden addressed the Negro problem. It is worth noting that Blyden's vision of Euro-Christian education underwent many changes. Before 1870s, Blyden seemed to get behind this type of education. In praising the work of Christian missions, Blyden (1856) wrote: "Christian colonies, standing like a chain of light along the benighted shore and spreading their civilizing and recovering influences among the surrounding degradation and barbarism" (p.29). Blyden believed that what worked for the European would inevitably work for the Africans. In this respect, he was at odds with giving a "peculiar type of education for Africans". Instead, Blyden (1862) advanced that the African was "part of the human family", and so he shared the "intellectual needs" that dictated the appliance of the "same fundamental principles" (p.25). However, Blyden visits to Egypt and the University of Beirut mushroomed in the alteration of such claims. Blyden averred that European missionary education was debasing, aiming in the first place to mistaken, distort, and alienate the African of his own identity. It only produced a despoiled African, contaminated by Euro-centric modes of existence, and a life inconsistent with his own. Blyden (as cited in Tibebu, 2012) wrote these words:

The evil, it is considered, lies in the system and method of European training to which Negroes are, everywhere in Christian lands, subjected, and which everywhere effects them unfavourably. Of a different race, different susceptibility, different bent of character from that of the European, they have been trained under influences in many respects adapted only to the Caucasian race (p. 51)

Now the African fell victim to a brutal type of slavery that was of the mind: "The slavery of the mind is far more destructive than that of the body," alleged Blyden (1872:p.13). This process

Arab World English Journal for Translation \& Literary Studies 
canalized in making Africans imitators, not inventors (Conyers, 1998). The African heroworshiped the European model to such an extent that he was blind to its faults. Blyden (1888) conveyed that Euro-Christian system of education was a means to engrave "a practical inferiority" and entrenched the African with "the faults rather than the virtues of their models" (p.88).

To remedy the delinquencies of African education, Blyden espoused for the creation of a West African university. Blyden had long been an advocate for a Pan-West African unity because of his great touch with West African cities. The establishment of a West African university was an articulation of this held belief. Blyden believed that the creation of a West African university was the best means to development and progress. Blyden (as cited in Conyers, 1998) addressed the governor of Sierra Leone about his proposal on 6 December 1872:

The more I reflect upon the subject, the more I am convinced that we can have no thorough and permanent reform- no proper development and growth- without the means being afforded of a liberal education to the youth (p.110)

Liberal education was not confined to the study of classics and European studies. Rather, it embodied an emphasis on African-centred education. The latter would defuse among Africans an education that did not interject with their "native instincts" and, in a way or another, did not make the native African "out of harmony and sympathy with their own countrymen....". Moreover, a purely African education would produce a "correct education" for the African. A correct education, on the other hand, would implant "self-respect", "growth and efficiency" and "a fitness for one's sphere of life and action" (Blyden, 1872:p.07).

The need to reformulate Euro-Christian education promulgated an assessment of Christianity. For Blyden, the Africans remained prone to the glaring abuses of European Christianity. He felt compelled to conjure up how Christianity was damaging to the Africans. For Blyden, Christianity represented the highest form of human endeavor. He sought Christianity as the "ultimate and final religion of humanity," a "truly" manifestation of God's words that would raise "mankind to the highest level" (July, 1967:p. 227). Yet, the Christian Negro experience with Christianity was malign. Blyden was at odds with how the attitudes of Christian missionaries were antithetical to God's Christianity. He constantly showed the "dissimilitude" and "disproportion" between God's message and preachers' attitude. By this, Blyden averred that "the triumph of Might over Right" helped diffuse Christianity among Negroes. This vehement hostility came up with a Christian Negro "abnormal in his development". There was nothing of an African character, but "easy prey to the Europeans". According to Blyden (1888),

From the lessons he every day receives, the Negro unconsciously imbibes the conviction that to be a great man, he must be like the white man. He is not brought up-however he may desire it-to be the companion, the equal, the comrade of the white man, but his imitator, his ape, his parasite (p.44) 
Accordingly, European missionaries (as cited in Conyers, 1998, p.150) sought the African mind as "Tabula rasa". A blank space where "everything is to be destroyed, replaced by something new and foreign".

The African faced the painful dilemma of having "God portrayed as other than self" (Akbar, 1984; p.54). Blyden espoused that the image of God exhibited itself in the "physical characteristic of a foreign race," which utterly had a depressing moral effect on the Negro. In a letter to Majola Agbebi, founder of the Native Baptist Church of Lagos, Blyden (as cited in Conyers, 1998) described the painful situation of the Christian Negro:

The European teacher, especially the Anglo-Saxon, hampered by dogmatic creed, cannot help trying not to Christianize but to Europeanize or Anglicize the native. He brings with him his prejudices, his faith in a natural inequality, and his profound disbelief in any race but his own....The great drawback in the character of the Negro who has been subject to training under the doctrines and formalities of European Christianity is his unwillingness to stand up as an African. He does not like to be odd. He is ashamed of anything that does not confirm to the European standard or represent European conceptions (p.158)

To get rid of this dilemma, the idea of creating a purely independent African church stood as a central premise to re-model African Christianity. For Blyden, the African must go on his line. There would never be an African imitator, but an inventor (Conyers, 1998). Through an independent African church, the African would forge a holistic amalgam of intellectual and educational paradigms consistent with his environment. The process would mold Christianity to suit the African socio-cultural estate and yield Africans to be independent and intellectually allegiant to the race.

\section{Blyden's Philosophy and the Emergence of West African Nationalism}

European colonialism in West Africa dated back to the $15^{\text {th }}$ century when early explorers of the West African coasts returned to Europe with news of African riches. European nations took no time to grasp at the chance and secure portions of the newly discovered lands. The process of explorations found great stimulus with the discovery of the Americas and the emergence of the Trans-Atlantic slave trade which lasted for nearly four hundred years. New World plantations quickened the need for African slaves and unfolded vigorous competition between all European rivals to have a monopoly over the West Coast of Africa. Up to the beginning of the nineteenth century, the English, Portuguese, French and Dutch occupied many areas in West Africa, but because of intense rivalry and wars, most of these posts did not develop into colonies. However, by the end of the century, Europeans consolidated their presence in West Africa in a period known in history as the scramble for Africa (1881-1914). At that time, European nations agreed on the partition of Africa to avoid clashes that hindered their progress in the region and, thus, exposing Africa and Africans to the painful and malignancy experience of European imperialism (Mostefaoui, 2010)

Arab World English Journal for Translation \& Literary Studies 
Because of increased colonial domination and racial prejudice, many West African intellectuals resisted European intentional attempts to demoralize them and exploit the African riches. These intellectuals owed their ideas to Blyden. They were much influenced by Edward Blyden's concept of the African personality, and denounced the rejection to be absorbed by Western values. In Sierra Leone, James Africanus Beale Horton, one of Blyden's friends, disdained Europeans appeals of Black's inferiority and believed that all races were equal. Horton (as cited in Meberbeche, 2010:p.137) expressed this belief in his book West African Countries and Peoples. He wrote, "I claim the existence of the attribute of a common humanity in the African or the Negro race...there exist no radical distinctions between him and his more civilized confrère". Horton also sought giving an African-centred education. Like Blyden, he believed education to be the best means for African's regeneration. He led many attempts to establish a medical school for Sierra Leoneans, while campaigned for the creation of a West African University that would offer courses in African philosophy and languages (Meberbeche, 2010). In Nigeria, much of inspiration derived from the thoughts of Edward Blyden. Mbonu Ojike criticized Europeans anthropological theories that depicted aspects of African societies as "a passing culture". As an admirer of Blyden, Ojike (as cited in Bouchemal, 2017:p.63) insisted that these societies were "too stable to be unproductive, too dynamic to be static, too dignified to be unimpressive, too African to be Western.". Jacob Kehinde Coker also leveled severe criticism at European Christianity. Coker (as cited in Bouchemal, 2017:p.57) opined that the African received Christianity as a foreign religion. As a result, he continued, "Many Africans had been spiritually lost because of the evils of the hypocritical life of the mission churches". This damaging situation led them to embrace Blyden's ideas and call for a purely African Christianity. A group of intellectuals formed a group known as Orunlaism. The group (as cited in Bouchemal, 2017:p.58) demanded for a re-Africanization of European Christianity. They appealed "Scrap the imported religion ... (there can be no) political emancipation without spiritual emancipation ... Paint God as an African,...the angles as Africans,...the Devil by all means in any color than an African,... and thou shalt be saved".

In the Gold Coast, the focus of this study, intellectuals' response to Blydenic philosophy was very quick. In 1874, the development of British colonial system and the eventual erosion of native institutions led to intellectuals' frustration and disappointment. The British colonial government raced to supplant native tribunals with a new British judicial system. The British attempted to weaken the power of kings and chiefs and made them indirectly controlled by the British authorities. Moreover, there was systematic exploitation of the African riches, which made people suffer from poverty and ignorance. Within this atmosphere of racial prejudice and colonial hegemony, intellectuals found in the ideas of Edward Blyden an outlet to address their grievances toward colonial oppression. Among these intellectuals stood J.E. Casely Hayford as the one who addressed the African problem, using Blyden's anthropological, ideological, and theological standpoints.

\section{Blyden's philosophy and Its Impact on J. E. Casely Hayford}

Joseph Ephraim Casely Hayford was born on 29 September 1866 in Cape Coast, Ghana. In his childhood, Hayford attended Wesley Boys' High School and moved to Fourah Bay College in Freetown, Sierra Leone where he met Edward Wilmot Blyden and became one of his friends. In 
the Gold Coast, he became a high school teacher then principal at Accra Wesleyan Boys' High School. Between 1885 and 1888, he edited the Western Echo and later the Gold Coast Chronicle between 1890 and 1896. In 1893, Hayford went to London to pursue his study at the Honourable Society of the Inner Temple, and at Peterhouse, Cambridge. When he returned, he helped establish the Mfantsipim School in 1904. By 1912, Hayford became the president of the Aborigines' Rights Protection Society, an anti-colonial organization (Darko, 1985). Up to 1930, Hayford was deeply involved in political activism that stemmed from his rejection to colonial monopoly of the social and economic life of the ordinary citizen. He took part in many international events for African emancipation and called for the creation of a Pan-West African unity through his body the National Congress of British West Africa. Hayford also published many books that revealed his hope for Africans' ideological purity and allegiance to the race. Through his writings, he constantly showed how he was an admirer of the work done by Blyden. Hayford (1911) wrote:

Edward Wilmot Blyden has sought for more than a quarter of a century to reveal everywhere the African unto himself; to fix his attention upon original ideas and conceptions as to his place in the economy of the world; to point out to him his work as a race among the races of men ; lastly, and most important of all, to lead him back unto selfrespect (p.163)

Hayford's words showed how he had an avid interest in Blyden's ideas and it was not a surprise to find most of his words and actions in compliance with Blyden's ideas and actions. As such, this section attempts to show this resemblance in the intellect and actions of both men.

As stated by Blyden, Hayford reacted against Black's inferiority and called for blacks to start their mission of progress. Hayford (1911) disdained race theories that contemplated Africans as "primitive", "barbarous", and "pagan". He vehemently protested against these malicious ideas that intended to precipitate a "national and racial death" and longed to prove the reverse. He conveyed, "before ever the British came into relations with our people, we were a developed people" (p.17). By this, Hayford propounded that the African had his own "native institutions", which marked the existence of a religious, municipal, commercial and judicial systems. Like Blyden, Hayford contended that the African had yet its mission to fulfill in Africa and the universe. In December 1929, in a meeting of the National Congress of British West Africa, Hayford (as cited in Ugonna, 1977) addressed the public in these highly sensitive words:

In these days when there is a tendency among the races of men to come together in their natural groups, it will be insincere for us to pretend that African nationhood does not interest us...Indeed while propagandists of another race are spreading abroad doctrines which may submerge our continent and make the black man perpetually a hewer of wood and drawer of water, it will be criminal in us to remain silent, and to pretend that those matters do not concern us. (p.162)

Hayford advocated that people of all races recognized the need for unity for self-empowerment. The African more than other races, should carve to come together to fight the derogatory views 
AWEJ for Translation \& Literary Studies Volume, 4 Number 2 May 2020

Blyden's Philosophy and Its Impact on West African Intellectuals

Bouchemal \& Senouci

about the African. He continually realized that African progress depended much on reviving native institutions. Hayford (1903) felt compelled to pressure on British authorities to let people "develop upon the national lines of their own institutions" (p.19). As such, he shared Blyden's view about the damaging effect of European influence. He believed it a mistake to deny Africans the ability to think, progress, and mainly chain them to European mental incarceration. Accordingly, the preservation of native institutions must be the responsibility of all Africans who showed allegiance to the race. For Hayford, it was high time for Africans to resent European influences over them and loudly tell the world that "there is an African law and an African culture; that the African has institutions and a state form of his own" (Mark, 1903:p.22).

For Hayford, African imitation of the European resulted in a cultural abortion. Like Blyden, Hayford believed that the African lost his cultural integrity and was alienated, distorted, inferiorized, and made ashamed to stand up as an African. In his influential novel Ethiopia Unbound, Hayford used the character of Tom Palmer, as an example of Africans who were misled to live in two worlds. As a leader of the community, Palmer, dressed like a European, married only one wife that signified his intense attraction to be like the white men. After all, Palmer discovered how he was deceived by a ruthless zeal to disciple all that was Western. His cultural awareness led him to dress African and to get more than one wife. Moreover, a similar disdain to the contaminated situation of the African centered on monogamy. A man in African societies could marry more than one wife. With an imitation of Western marital system, however, the Africans became in a nasty situation. According to Hayford (1911), "embracing Christianity invariably meant for him adopting subterfuges and chicanery to cover up the way of the old life, which not all the spiritual graces could help him to brush aside"'(p.192). This blind mimic of Westerners led Ekuba, one of his characters, to lead a life of misery because she refused to be one of the wives of Tandor-Kuma. Her pain, affirmed Hayford, was only a result of her contaminated understanding of European modernity. By this, Hayford endorsed Blyden's opinion and called for the Africans to despise Western influences and believe in their capacities. According to Hayford (1911), "African manhood" demanded that the Ethiopian "should seek not his opportunity, or ask for elbow room from the white man, but that he should create the one or the other for himself" (p.182).

Hayford considered the African personality to be incompatible with the European personality. In his novel "Ethiopia Unbound", Hayford bolstered up a feeling of pride in the African personality. The main two characters, Kwamankra and Whitely, represented the African and Western standpoints, respectively. The two characters are "ideas personified," argued Ugonna (1977), where Hayford intended to compare African cultural institutions with Western models (p.163). Kwamankra exhibited the essence of African personality. He presented a counterdiscourse of Africans depicted by Europeans. He is a spiritually religious character, mostly tight to God. On the other hand, Whitely presented the emptiness of European personality. For Whitely, belief and non-belief were the same. He repeatedly revealed doubt about the divinity of Christ, even though he was a theology student (Ugonna, 1977). Moreover, the African personality had a significant influence on the moral and philosophical history of ideas. In theology, much of the European principles of God Christianity were utterly African. Hayford espoused to demonstrate the fact that knowledge about Christ was only an African initiation. According to Hayford (1911),

Arab World English Journal for Translation \& Literary Studies 
these beliefs were "borrowed from the Romans, who were pagans like ourselves, and who, indeed, had much to learn from the Ethiopians through the Greeks" (p.5). Additionally, Hayford dilated upon African religion to prove his argument. For the Fanti, the word "Nyiakropon", means God, entails "combination of distinct root ideas in one word". Set separately, "Nyia", "nuku" ,"are" ,"oye" "pon", the word means "Great". This philosophical discussion of the principles of African religion was one way to negate European claims of African "barbarism" and to denounce that much of Europe's philosophical, ethical and religious beliefs were African (Ugonna, 1977). Hayford (1911) claimed, "nation that can in the next century, show the greatest output of spiritual strength, that is the nation that will lead the world, and as Buddha from Africa taught Asia, so may Africa again lead the way"(p.09). By this, Hayford concurred with the view of Blyden that the spirituality of the African personality, by reverse to the materialistic and scientific endeavor of the European personality, would make Africans head other nations.

Hayford believed that education was the best means for national conservancy and evolution. Like Blyden, He found that different government and missionary education institutions detached the African of his origins. Euro-Christian education made the African completely imitator of the Europeans. Hayford pointed out that European education "denationalized" Africans and made them humble and submissive to European influences. The Africans received an education that prepared them to be disciplinarians of the Europeans. Hayford (as cited in Darko, 1985) lamented this state of affairs in the 1929 presidential address to the Fourth National British West African Congress in Lagos:

But it is obvious that we cannot forever remain babes and suckling and yet complain when our destiny is being decided for us by others. History tells us how other people have risen to nationhood, to economic security and power. We must tread the same path if we would see salvation as a people; and that path is primarily educational. We have our ideals; we have our interests to safeguard, we have our line of evolution, and we cannot afford to leave them in the hands of others to manipulate them for us. There must be an educational awakening throughout West Africa greater than at any time in African history, and when this Pentecost breaks in upon us, we shall begin to tread the sure path to national emancipation (p.111)

According to Hayford, education would stimulate a widespread awakening among Africans. It would uplift the African to a status where he could see the world of his philosophy, uncontaminated by European influences. As a tool for national emancipation, Hayford insisted that the diffusion of education throughout West Africa would shape new Africa mentally independent of European incarceration and physically self-reliant to lead its own destiny.

Hayford called for the foundation of a West African university. Hayford too believed that the creation of a West African university would heal the distorted African manhood, and selfempowered the African to find his way among nations. By this, the new scheme would offer the African student a chance to reinforce his ties with his language, religion, customs, and tradition.

Arab World English Journal for Translation \& Literary Studies 
AWEJ for Translation \& Literary Studies Volume, 4 Number 2 May 2020

Blyden's Philosophy and Its Impact on West African Intellectuals

Bouchemal \& Senouci

An excellent example of Hayford's sentiments regarding a West African University is quoted at length from Ethiopia Unbound:

Upon the opening of the National University, Kwamankra gave up newspaper work and joined the University staff. He was foremost in bringing forward schemes to prevent the work of the University becoming a mere foreign imitation. He kept constantly before the Committee from the first the fact that no people could despise its own language, customs, and institutions and hope to avoid national death. For that reason, the distinctive garb of students, male and female, was national with an adaptability suggestive of the advanced state of society. It was recognized that the best part of the teaching must be done in the people's own language, and soon several textbooks of known authority had, with the kind permission of authors and publishers, been translated into Fanti, thereby making the progress of the student rapid and sound. (Hayford, 1911, p. 16-17)

Through the realization of his scheme, Hayford had the hope of improving the lot of his fellowAfricans. Like Blyden, he believed that a purely African university would provide a correct education. The latter would bring African one-step closer to their institutions that had long been damaged by European influences.

Hayford also leveled severe criticism at European Christianity. Identical to Blyden's view, he insisted on the mystifying effect of Christianity brought to Africans and was at odds with how such a system confused and deluded the African of his real estate. Hayford always showed that missionaries' lack of knowledge of indigenous beliefs led them to deceive the Africans. According to Hayford (1903), "yet what a different state of things would prevail if the missionary had first studied the Religious system of the Native before trying to impose it, or, which is worse, before introducing new one" (p.105). For Hayford, missionary bodies had never attempted to understand African religious beliefs. They utterly superseded them to advance their own obstructive and detrimental Christianity. Speaking about missionaries failed project, Hayford (1911) emphasized:

I cannot help but agree with you ....and I, for one, feel nothing but pity for the kind of ignorance which scoffs at what it does not understand. The fact is that you Christians have not taken the trouble to understand any other system but your own (pp.27-28)

By doing this, Hayford averred that the missionaries betrayed the African by detaching him from his own religious beliefs and retarded his spiritual development by introducing a system that did nothing but distorted his religiosity and relation to God. Furthermore, Hayford (1903) claimed that the foundation of a purely independent African church would be a source of "the mine of truth and inspiration" (pp.102-105). He proposed the establishment of a "National Church" that would develop an African character through the incorporation of indigenous religious beliefs in teaching. Similar to Blyden, hayford (1911) consistently sought an independent African church as the only path for Africans' real emancipation and warned Africans that the only way to survive was to throw the burden of European Christianity:

Arab World English Journal for Translation \& Literary Studies

ISSN: 2550-1542 | www.awej-tls.org 
If my people are to be saved from national and racial death, they must be proved as if by fire...by the practice of a virile religion, not by following emasculated sentimentalities which men shamelessly and slanderously identify with the Holy One of God, His son, Jesus Christ (p.75)

Hayford sought the creation of an independent African church as the only path for racial and national survival. The church would subside the harmful effects of European Christianity and get Africans back to their religious real estate. Moreover, the Church would instill in the Africans a sense of autonomy to revive their institutions and initiate other projects for their social, economic and political progress.

\title{
Conclusion
}

The purpose of the present study was to examine the impact of Blyden's philosophy on J.E.Casely Hayford of the Gold Coast. The article traced the evolution of black's protests that were a result of racial prejudice and subjugation, and briefly exposed different facets of Blydenic philosophy. The findings revealed that Blyden' ideas and intellect influenced many West African intellectuals. Believing in Blyden's principles of African unity and the African personality, these intellectuals engaged in systematic resistance to the colonial enterprise and its degrading effects on native institutions. They championed the cause of their fellow Africans to lead a life of dignity and manhood.

Furthermore, the article concluded that Hayford, similar to his fellow West Africans, promoted the psychological welfare of the African people and campaigned to let Africans re-build their distinct African personality. His significant preoccupations were to promulgate a sense of oneness and cooperation among people of the African race and to disdain the disparaging views about Africans' inferiority and barbarism. Like Byden, Hayford spearheaded and fashioned new paths of Africaness and determination to grapple with different national and racial challenges to stand out as Africans. It is essential to manifest efforts to keep the legacy of Edward Wilmot Blyden and encourage further investigations into its impact on pre-independent Africa, and why not much more modern Africa.

\begin{abstract}
About the authors:
Ahmed Bouchemal holds a Magister degree in Commonwealth Literature and Civilization. He is an assistant teacher at the University of Djelfa, Algeria. Currently, he is preparing his $\mathrm{PhD}$ thesis at the university of Abou Bekr Belkaid, Tlemcen, Algeria. His major research interests are British history, cultural studies, commonwealth history. https://orcid.org/0000-0003-3422-1656
\end{abstract}

Prpf. Faiza Meberbeche Senouci is a senior lecturer at the University of Tlemcen, department of English. Currently, she is in charge of different courses. Her major interests are Pan-African History, American civilization, Culture, Identity and Religion. https://orcid.org/0000-0001-51539987

Arab World English Journal for Translation \& Literary Studies 
AWEJ for Translation \& Literary Studies Volume, 4 Number 2 May 2020

Blyden's Philosophy and Its Impact on West African Intellectuals

Bouchemal \& Senouci

\section{References}

Akbar, N. (1984). Chains and Images of Psychological Slavery. Michigan University: New Mind Productions.

Blyden, E.W. (1856). A Voice from Bleeding Africa on Behalf of Her Exiled Children. Liberia: $\mathrm{G}$, Killian Printer.

Blyden, E.W. (1862). Liberia's Offering. New York: John A. Gray.

Blyden, E.W. (1872). The West African University. Correspondence Between E. W. Blyden and His Excellency J. Pope Hennessy, C.M.G, Administrator in Chief of the West African Settlements. Freetown: Negro Printing Office.

Blyden, E.W. (1888). Christianity, Islam, and the Negro Race. Baltimore: Black Classic Press. Blyden, E.W. (1908). African Life and Customs. London: C. M. Philis.

Bouchemal, Ahmed. (2017). Western Education and Elite Nationalism in Nigeria: 1882-1929. (Magister Dissertaion). Amar Thellidji University, Algeria.

Conyers, J (1998). An Afro-Centric Study of the Philosophy of Edward Wilmot Blyden (Unpublished Doctoral Dissertation). The Temple University.

Darko, F. Samuel (1985). An Historical Inquiry into the Development of Higher Education in Ghana 1948-1984: A Study of the Major Factors that Have Controlled and Inhibited the Development of the Universities of Ghana",( Doctoral Dissertation), North Texas State University.

Gloria Chuku. (2014). African Intellectuals as Cultural Nationalists: A Comparative Analysis of Edward Wilmot Blyden and Mbonu Ojike. The Journal of African American History, 99(4), 350-378. DOI:10.5323/jafriamerhist.99.4.0350

Hayford, C (1911). Ethiopia Unbound: Studies in Race Emancipation. London: C.M. Philips. Hayford, C (1903). Gold Coast Native Institutions. London: Sweet and Maxwell Isaac Knapp. July, R (1967). The Origins of Modern African Thought. New York: Frederic A. Praeger

Lynch, H (1967). Edward Wilmot Blyden: Pan-Negro Patriot 1832-1912. London: Oxford University Press.

Mark, C (1903). Mary H. Kinsley from an African Standpoint. London: Bear and Taylor.

Mostefaoui, Aziz (2011). The Evolution of Pan-Africanism and the Gold Coast Nationalism from the Origins to 1960. (Doctoral Dissertation). Oran University 02, Algeria

Meberbeche, Faiza (2010). Pan-Africanism and Its Impact on the Sierra Leonean Elite up to 1945. (Doctoral Dissertation). Abou Bekr Belkaid University, Tlemcen, Algeria

Spreading Pan-African Ideas in America. Retrieved from: http://www.columbia.edu/ hcb8/EWB_Museum/America.html.

Tibebu, Teshale (2012). Edward Wilmot Blyden and the Racial Nationalist Imagination. University of Rochester Press

Ugonna, N. (1977). Casely Hayford: The Fictive Dimension of African Personality. Ufahamu: A Journal of African Studies, 7(2). Retrieved from escholarship.org/uc/item/19j2b8kx

Zack, N. (2017). The Oxford Handbook of Race and Philosophy. London: Oxford University Press

Arab World English Journal for Translation \& Literary Studies 